\title{
WORK POSTURE AND MUSCULOSKELETAL DISORDERS OF COCONUT PEELER WORKERS IN SEI APUNG VILLAGE, ASAHAN REGENCY
}

\author{
Putra Apriadi Siregar $^{\mathrm{a}^{*}}$; Muchliza Rizwany ${ }^{\mathrm{b}}$; Nurhayatic \\ a, b,c Universitas Islam Negeri Sumatera Utara ; 1 IAIN Street ; Medan ; Indonesia
}

\begin{abstract}
Posture and certain activities towards work equipment have the potential to cause health problems, even disease. One disease that is identical to workers who have problems with posture is musculoskeletal disorders. This research has a purpose of analyzing the relationship between work posture with musculoskeletal disorders of coconut peeler workers. This research has quantitative research with cross-sectional design. The sample of this research was 52 workers with purposive sampling technique. The data obtained by observation and interviews used Rapid Entire Body Assessment (REBA) and Nordic Body Map (NBM) questionnaire. The analysis relationship used Spearman Rho correlation test with a significance level of $95 \%(\alpha=0,05)$. Based on the result of the studied show working period of 1 to 5 years as 33 people $(63.5 \%)$, work postures is more spread over the value 3 (high category) as 34 people $(65.4 \%)$, musculoskeletal disorders was mostly in the moderate as 31 people $(59.6 \%)$. A significant relationship between work posture with musculoskeletal disorders $(\mathrm{r}=0.534)$. As a suggestion to take a break or stretching muscles, add hand braces or elbows to prevent the risk of complaints, and to modify the seat to reduce the risk of complaints in the lower back area.
\end{abstract}

Keywords: work posture; musculoskeletal disorders; coconut peeler workers

\section{Introduction}

Musculoskeletal disorders (MSDS) are a condition that affects the musculoskeletal system that can occur in tendons, muscles, joints, blood vessels, and nerves in limbs (Akbar, 2016). Work posture and repetitive static movements are ergonomic exposures that can be occupational factors associated with musculoskeletal disorders.

Musculoskeletal disorders are complaints that a person feels in the muscles and skeletons, with different levels of complaints ranging from minor complaints to very severe complaints. Excessive loading on the muscles will result in less blood flow to the muscles. The decrease in blood flow to the muscles causes a decrease in the supply of oxygen to the muscles so that it will inhibit the carbohydrate metabolism process and there will be an accumulation of lactic acid which can cause muscle pain(Tarwaka, 2015).

\footnotetext{
*) Corresponding Author (Putra Apriadi Siregar)
} E-mail: siregar.putra56@gmail.com
Musculoskeletal disorders occupy the highest position, which is around $40 \%$ in terms of expenditure on compensation costs paid by companies for workers as a result of work-related accidents and diseases (Jalajuwita, 2015). Based on data from BPJS Ketenagakerjaan (assurance of working), in 2018, there were 114.148 workplace accidents.

The results of research conducted by regarding the relationship between work postures and complaints of musculoskeletal disorders (Marinawati, 2016). The body that the respondents felt the most pain in was the shoulders, fingers and back. In line with research conducted by on home industry work in Surabaya that respondents' complaints are finding on the back and right shoulder (Permatasari, 2017). Complaints of musculoskeletal disorders with their correlation to work posture and oil palm harvesters found that out of 60 workers (Sumihardi, 2015).

Coconut peeler is a job done by the majority of women in Tanjung Balai to help the family 
economy (Yafiz, 2015). Checking is one of the jobs performed by workers in the informal sector jobs. Although the informal sector has contributed a lot to both the economy and job providers, it cannot deny that the health conditions of its workers are still worrying (Tjahayuningtyas, 2019).

Based on the profile of the Sei Apung Puskesmas, Tanjung Balai sub-district, Asahan Regency, in 2017, muscle and tissue system diseases ranked 8th out of the top 10 most common diseases in the Sei Apung Puskesmas working area, with 460 cases recorded. Based on a preliminary survey and a short interview using a Nordic Body Map (NBM) questionnaire to 10 coconut hullers, eight workers experienced musculoskeletal complaints on their left upper arm, followed by seven right upper arms as many as eight waist workers, and all workers experienced complaints. Musculoskeletal on the left elbow and none of the workers had no MSDS complaints at all.

Based on observations and short interviews with coconut peelers, it found that the working time was 5-8 hours in one day depending on the number of coconuts supplied by the collectors. Through a brief observation, workers poke coconuts in a sitting position bent over continuously during their work. There is no fixed rest time that implemented, and workers do not think about their rest time when they feel tired, then they take a short break because they are pursuing the target number of coconuts which is measuring in $\mathrm{kg}$. According to information obtained by workers, the price for 1 $\mathrm{kg}$ of peeled coconut paid 250-300 IDR.

\section{Method}

This type of research used a quantitative design with the design of this study used a cross sectional approach (cross-sectional). The location of this research is in Sei Apung Village, Tanjung Balai District, Asahan Regency. The research period was carried out from December 2019 to April 2020. The population used in this study were all coconut peeler in Sei Apung Village, totalling 150 people. The sample of this study used the cross-sectional Lemeshow formula to determine the number of samples and then obtained 52 samples.

The sampling technique in this study used purposive sampling, namely by determining a sample of the total population of coconut pluckers in Sei Apung village based on inclusion and exclusion criteria. The inclusion criteria in this study were coconut peeler working in Sei Apung Village during the research period. Respondent resides in Sei Apung Village for at least six months. Have an age of 18-55 years. Have worked as a pruning coconut for at least one year.

The variables studied were age, gender, years of service, length of work, last education, work posture, and Musculoskeletal Disorders. The instruments used in this research are Nordic Body Map (NBP) questionnaire to detect pain in the musculoskeletal area felt by respondents and individual factor data (age, latest education, length of work and years of work), REBA (Rapid Entire Body Assessment) assessment sheets to get the risk level of work attitudes. A camera to document the respondent's work attitude at work and a regular protractor to measure the angle formed in the work posture. The data analysis used was univariate analysis and bivariate analysis using the Spearman Rho Correlation Test with a significance level of $\alpha=0.05$.

\section{Result and Discussion}

Table 1. Distribution of Respondent Characteristics, Work Posture and Musculoskeletal Disorders

\begin{tabular}{|c|c|c|}
\hline Age & $\mathrm{n}$ & $(\%)$ \\
\hline 18- 30 Years & 23 & $44.2 \%$ \\
\hline$>30$ Years & 29 & $55.8 \%$ \\
\hline Sex & $\mathrm{n}$ & $(\%)$ \\
\hline Male & 0 & $0 \%$ \\
\hline Female & 52 & $100 \%$ \\
\hline Length Of Working & $\mathrm{n}$ & $(\%)$ \\
\hline $1-5$ Years & 33 & $63.5 \%$ \\
\hline$>5$ Years & 19 & $36.5 \%$ \\
\hline Education & $\mathrm{n}$ & $(\%)$ \\
\hline Primary School & 2 & $3.8 \%$ \\
\hline Junior High School & 10 & $19.2 \%$ \\
\hline Senior High School & 40 & $76.9 \%$ \\
\hline Work Posture & $\mathrm{n}$ & $(\%)$ \\
\hline 0 & 0 & $0 \%$ \\
\hline 1 & 0 & $0 \%$ \\
\hline 2 & 18 & $34.6 \%$ \\
\hline 3 & 34 & $65.4 \%$ \\
\hline 4 & 0 & 0 \\
\hline Risk of Musculoskeletal Disorders & $\mathrm{n}$ & $\%$ \\
\hline Lower & 12 & $23.1 \%$ \\
\hline Medium & 31 & $59.6 \%$ \\
\hline High & 9 & $17.3 \%$ \\
\hline Very High & 0 & $0 \%$ \\
\hline Risk Category & 12 & $23.1 \%$ \\
\hline Total & 52 & 100 \\
\hline
\end{tabular}

Based data was obtained that of the 52 respondents, there were 23 people $(44.2 \%)$ who had an age range between 18 and 30 years. Moreover, respondents have an age range above 
30 years as 29 people (55.8\%). All respondents, $100 \%$ have female gender. Data was obtained that of the 52 respondents there were 33 people $(63.5 \%)$ who had a working period of 1 to 5 years and 19 people $(36.5 \%)$ who have a work period of more than five years.

Based on data respondents with a service period of 1 to 5 years is greater than that of respondents who have worked for more than five years. Data obtained from the 52 respondents, there are 39 people (75\%) who worked for 5 hours or more in one day. Based on data respondents with the frequency of respondents who worked more than 5 hours was higher than those who worked less than 5 hours.

The latest educational data for coconut peeler consisted of primary school to senior high school. Based on table 4.4, the most recent respondents' education was senior high school as many as 40 people $(76.9 \%)$ and the least was elementary school, namely two people (3.8\%).

The distribution of respondents according to work postures is more spread over the value 3 (high category) of $65.4 \%$ and value 2 (medium category) of $34.6 \%$. The distribution of respondents about Musculoskeletal Disorders was mostly in the moderate category as many as 31 people $(59.6 \%)$, and the lowest was the high category as many as nine people $(17.3 \%)$.

Table 2. Correlation Between Work Posture With Musculoskeletal Disorders

\begin{tabular}{ccc}
\hline \multicolumn{2}{c}{ Spearman's Rho } & $\begin{array}{c}\text { Score of } \\
\text { Musculoskeletal } \\
\text { Disorders }\end{array}$ \\
\hline $\begin{array}{c}\text { Total score of } \\
\text { Work Posture }\end{array}$ & $\begin{array}{c}\text { Correlation } \\
\text { coefficient }(\mathrm{r}) \\
\text { Sig (p value) }\end{array}$ & 0.534 \\
\hline
\end{tabular}

Based on the results of the Spearman Rho correlation test, it was obtained a significance of $<0.001$. These results indicate that there is a significant relationship between work postures and complaints of musculoskeletal disorders in coconut pockets in Sei Apung Village. This relationship has a strong correlation and a complimentary pattern, as evidenced by the correlation coefficient $r=0.534$. Means that the higher the risk of work posture, the higher the risk of Musculoskeletal Disorders.

In this study, work posture was measured using a Rapid Entire Body Assessment (REBA) using scoring on body parts, including the neck, body or back, legs, upper arms, forearms and wrists. The score will also be added with the coupling score (handle or tool), loading score, and activity score. After all the scores are added up, it is known that workers are at risk with their ergonomic activities or not. The risk categories include negligible, low, medium, high and very high.

Uncontrolled use of muscle work, continuous activity, static body position for an extended period can cause complaints to the skeletal muscles known as musculoskeletal complaints. Based on the results of the study, the parts of the body that have significant differences are the neck position that bends flexion $>20^{\circ}$, the part of the body that bends down, the legs, and the upper arms. Meanwhile, for the assessment of work posture activities, it was found that there were parts of the body that were in a static position (fixed posture) for more than one minute, namely the legs. And there was repeated activity in a relatively small area $>4$ times/minute, that is, when the worker put down the coconut that had been peeled and took another new coconut to peel the husk.

Before calculating the work posture and MSDS complaints, the researcher first made observations to find out how the work position, load, tools used, and repetitive activities of workers. The characteristics of workers in the form of a length of work will have an impact on the illness they suffer (Iqbal, 2019).

The results showed a work posture with a low level of risk and high risk, while for MSDS complaints, it was found that all respondents were at low, medium, and high risk. In this case, workers reported frequent complaints or pain in the fingers, shoulders and back. This was obtained when researchers conducted interviews using the Nordic Body Map questionnaire sheet. Most of the respondents complained of pain in the shoulders, back, and fingers due to repetitive activities in the grip that they felt were less than ideal, as well as sitting in a bent position without a backrest which was carried out continuously for the following days (Wahyuni, 2019). At the same time, the worker must remove the coconut that has been peeled and take the next coconut so that the spine rotates when the body is bending . The activity of moving goods manually with a stiff bent body position that is carried out repeatedly is the cause of Musculoskeletal Disorders (Wicaksono, 2016).

On packing workers at PT. Djitoe Indonesia Tobako, that there is a strong enough $(r=0.439)$ and significant relationship between work posture and Musculoskeletal Disorders with a p-value of 0.019 and a positive correlation coefficient where the higher the risk level for 
working food, the higher the risk of Musculoskeletal Disorders (Arfiasari, 2014). This is caused by the work equipment factor that is not suitable so that it affects the work posture of the workers, which then also affects Musculoskeletal Disorders. The same thing was also explained the results was a significant relationship between the risk of work posture and the risk of musculoskeletal disorders complaints (Aisyah, 2014). Musculoskeletal Disorders are one of the occupational diseases that arise in the workplace. One of the Musculoskeletal Disorders occurs due to bad work posture. Work posture is the position of the body segment when doing work. In this study, it is recommended that workers improve their position while working, do stretching and employers make improvements to the workplace and perform technical engineering on work tools (Margarini, 2014).

This relationship has a strong correlation and a positive pattern, as evidenced by the correlation coefficient $r=0.534$. This means that the higher the risk of work attitude, the higher the risk of musculoskeletal complaints. Before calculating the work posture and MSDS complaints, the researcher first made observations to find out how the work position, load, tools used, and repetitive activities of workers. The results showed a work posture with a low level of risk and high risk, while for MSDS complaints, it was found that all respondents were at low, medium, and high risk. In this case, workers reported frequent complaints or pain in the fingers, shoulders and back. This was obtained when researchers conducted interviews using the Nordic Body Map questionnaire sheet. Most of the respondents complained of pain in the shoulders, back, and fingers due to repetitive activities in the grip that they felt were less than ideal, as well as sitting in a bent position without a backrest which was carried out continuously for the following days. At the same time, the worker must remove the coconut that has been peeled and take the next coconut so that the spine rotates when the body is bending. The activity of moving goods manually with a stiff bent body position that is carried out repeatedly is the cause of musculoskeletal complaints (Utari, 2015).

Packing workers at PT. Djitoe Indonesia Tobako, that there is a strong enough $(r=0.439)$ and significant relationship between work posture and musculoskeletal complaints with a p-value of 0.019 and a positive correlation coefficient where the higher the risk level for working food, the higher the risk of musculoskeletal complaints (Arfiasari, 2014). This is due to the work equipment factor that is not suitable so that it affects the work posture of the workers, which then also affects musculoskeletal complaints. Musculoskeletal complaints are one of the occupational diseases that arise in the workplace. One of the musculoskeletal complaints occurs due to bad work posture (Lestari, 2014). Work posture is the position of the body segment when doing work. In this study, it is recommended that workers improve their position while working, do stretching and employers make improvements to the workplace and perform technical engineering on work tools.

Workers can not merely ignore their physical health. Working with the right work attitude based on ergonomic principles, creating a comfortable work environment is an essential part of efforts to prevent the risk of disease and health problems in the workplace. Because every Muslim is obliged grateful for healthy favours that have been given to him and make the best use of this healthy period, therefore, we must take care of what Allah SWT has given us, including protecting our bodies to avoid complaints from the musculoskeletal system. The solution is to take preventive and control measures such as improving attitudes while working, implementing balanced rest periods according to working conditions, and ideal tools for workers.

\section{Conclusion and Suggestion}

Characteristics respondent for the age range were mostly dominated by age $>30$ years, high school graduates and equivalent dominated the average working period of 1-5 years, the average length of work of the respondents $\geqslant 5$ hours and the last education of the respondents. Mostly working period of 1 to 5 years, work postures is more spread over the value 3 (high category), musculoskeletal disorders was mostly in the moderate. This relationship has a strong correlation and a complimentary pattern, as evidenced by the correlation coefficient $\mathrm{r}=0.534$. Means that the higher the risk of work posture, the higher the risk of Musculoskeletal Disorders $(\mathrm{p}<0.001)$.

Workers should take breaks or stretch muscles when they begin to feel pain in some regions of the body such as the forearms, neck and back. Workers should use cloth made of 
gloves so that they are not slippery when holding the coconut husk peeler or add cloth wrapping to the handle of the tool, adding hand or elbow supports to prevent the risk of complaints in the area. Employers should modify reclining seats to prevent complaints in the lower back area.

\section{Acknowledgments}

Researchers would like to thank the local government of Sei Apung Village, Kisaran Regency who has helped a lot in the smooth running of this research. Researchers would also like to thank Universitas Islam Negeri Sumatera Utara for helping to run this research.

\section{References}

Aisyah, F. (2014). Hubungan Karakteristik Individu dan Posisi Kerja dengan Keluhan Musculoskeletal Disorders pada Pekerja Angkat-Angkut di Pergudangan PT AJG Gresik 2014. Universitas Airlangga.

Akbar, M. N. (2016). Hubungan Posisi Dan Masa Kerja Dengan Gangguan Sistem Muskuloskeletal Pada Perawat. UIN Alaudin Makasar.

Arfiasari, A. D. (2014). Hubungan Postur Kerja dengan Keluhan Muskuloskeletal dan Produktivitas Kerja Pada Pekerja Bagian Pengepakan di PT. Djitoe Indonesia Tobako. Pontificia Universidad Catolica Del Peru. Universitas Muhammadiyah Surakarta. Retrieved from https://core.ac.uk/download/pdf/1486008 76.pdf

Iqbal M. Pembinaan Dan Pengawasan Dinas Kesehatan Terhadap Kualitas Depot Air Minum Isi Ulang Di Kabupaten Simeulue Tahun 2018. Contag Sci Period Public Heal Coast Heal. 2019;1(1):1-10

Jalajuwita, R. N. (2015). Hubungan Posisi Kerja Dengan Keluhan Muskuloskeletal Pada Unit Pengelasan PT. X Bekasi. The Indonesian Journal of Occupational Safety and Health, 4(1), $33-42$. https:// doi.org/10.20473/ijosh.v4i1.2015.33 $-42$

Lestari, N. L. P. S. M. (2014). Pengaruh Stretching Terhadap Keluhan Muskuloskeletal Pada Perawat Di Ruang Ratna Dan Medical Surgical RSUP Sanglah. Universitas Udayana.

Margarini, A. F. (2014). Hubungan Faktor Karakteristik Individu, Faktor Ergonomis dengan Keluhan Subjektif Musculoskeletal Disorders (MSDs) pada Pekerja Konstruksi PT. X. Universitas Airlangga.

Marinawati. (2016). Faktor-Faktor yang Berhubungan dengan Keluhan Muskoloskeletal pada Pekerja Pemanen Kelapa Sawit di Desa Rantau Rasau Kecamatan Rantau Rasau Kabupaten Tanjung Jabung Timur Tahun 2016. Scientia Journal, 5(2), 180-186.

Permatasari, F. L. (2017). Hubungan Sikap Kerja Terhadap Keluhan Musculoskeletal Pada Pekerja Home Industry Di Surabaya. The Indonesian Journal of Occupational Safety and Health, 7(2), $220-239$. https://doi.org/10.20473/ijosh.v7i2.2018.23 $0-239$

Sumihardi. (2015). Keluhan Muskuloskeletal Disorders Hubungannya Dengan Sikap Kerja Pada Pemanen Kelapa Sawit. Poltekes Kemenkes.

Tarwaka. (2015). Ergonomi Industri Dasar-dasar Pengetahuan Ergonomi dan Aplikasi di Tempat Kerja (Pertama). Solo: Harapan Press Solo.

Tjahayuningtyas, A. (2019). Faktor Yang Mempengaruhi Keluhan Musculoskeletal Disorders (MSDs) Pada Pekerja Informal. The Indonesian Journal of Occupational Safety and Health, 8(1), $1-10$. https:// doi.org/https://doi.org/10.20473/ ijosh.v8i1.2019.1.

Utari, F. Y., Kalsum, \& Mahyuni, E. L. (2015). Hubungan Sikap Kerja Dengan Keluhan Muskuloskeletal Pada Penyortir Tembakau Di Gudang Sortasi Tembakau Kebun Klumpang SUTK PTPN II Tahun 2015. Lingkungan Dan Keselamatan Kerja, 1(1), 1-8.

Wahyuni, C. A. (2019). Hubungan Kesegaran Jasmani dan Sikap Kerja dengan Keluhan Muskuloskeletal Pada Pengrajin Manik Kaca di Jombang. Jurnal Keperawatan Muhammadiyah, 1(1), 106-110.

Wicaksono, R. E., Suroto, \& Widjasena, B. (2016). Hubungan Postur, Durasi Dan Frekuensi Kerja Dengan Keluhan Muskuloskeletal Akibat Penggunaan Laptop Pada Mahasiswa Fakultas Teknik Jurusan Arsitektur Universitas Diponegoro. Jurnal Kesehatan Masyarakat, 4(3), 1-10.

Yafiz, Muhammad , Yuzrizal, F. (2015). Pemberdayaan Perempuan Dalam Meningkatkan Kesejahteraan Ekonomi Masyarakat di Tanjung Balai. Medan. 